\title{
IMPLEMENTASI METODE PEMBELAJARAN MIND MAPPING DALAM MENINGKATKAN MOTIVASI BELAJAR SISWA PADA MATA PELAJARAN IPS TENTANG MANUSIA SEBAGAI MAKHLUK SOSIAL DI MI MARHATILLAH MATABE
}

\author{
Ida Laila \& Isa Anshori \\ UIN Sunan Ampel Surabaya \\ Idalaila.ha@gmail.com,isaanshori67@gmail.com
}

\begin{abstract}
One of the things that need to be considered in carrying out learning and learning activities is learning motivation. If the motivation to learn does not exist in students, then what happens is that students will be less enthusiastic in participating in learning or carrying out learning activities. So, if students lack motivation to learn, educators or parents must play an active role in growing that motivation. The use of less varied methods at MI Mardhatillah Sanalaok. Waru Pamekasan, especially in class IV, causes students' boredom and lack of enthusiasm for learning. In this case the teacher requires basic teaching skills in the form of variations in student teaching and the ability to design, implement various strategies or learning methods that are considered suitable for interests and talents and in accordance with the level of student development. Therefore, the lack of student motivation in social studies subjects is due to the approach used by the teacher in the learning process is still teacher centered and the learning methods used are less varied. So there needs to be an explanation of learning methods, one of which is the mind mapping method. In this study there are several problems discussed by the researcher. First, how to apply the mind mapping method. Second, how to increase students' learning motivation through the mind mapping method
\end{abstract}

Keywords: Learning Motivation, Mind Mapping Model, IPS

\section{PENDAHULUAN}

Manusia adalah makhluk sosial yang memiliki akal pikiran juga kemampuan berinteraksi secara individu maupun sosial dan pada dasarnya manusia tidak mampu hidup sendiri di dalam dunia ini baik sendiri dalam kontek fisik maupun dalam kontek sosial budaya. Dalam kontek sosial budaya, manusia membutuhkan manusia lain untuk saling berkolaborasi dalam pemenuhan kebutuhan fungsi-fungsi sosial 
satu dengan lainnya dan semua masyarakat pada hakikatnya membudaya dan berkebudayaan. ${ }^{1}$

Ilmu Pengetahuan Sosial atau IPS adalah bidang studi yang menghormati, mempelajari, mengolah dan membahas hal-hal yang berhubungan dengan masalahmasalah buman relationship hingga benar-benar dapat dipahami dan diperoleh pemecahannya. Ilmu pengetahuan sosial diartikan sebagai upaya pembinaan baik dari segi pengetahuan maupun kemampuan berfikir tingkat tinggi peserta didik yang diharapkan pada akhirnya memiliki kesadaran dan tanggung jawab yang tinggi terhadapdiri sendiri dan lingkungannya. ${ }^{2}$

Salah satu hal yang perlu diperhatikan dalam melakukan kegiatan belajar dan pembelajaran adalah motivasi belajar. Jika motivasi belajar tidak ada dalam diri siswa, maka yang terjadi adalah siswa akan kurang bergairah dalam mengikuti pembelajaran atau melakukan kegiatan belajar. Jadi, jika siswa kurang memiliki motivasi untuk belajar, pendidik atau orang tua harus berperan aktif untuk menumbuhkan motivasi tersebut.

Seorang pendidik yang profesional harus secara pro-aktif membangkitkan motivasi belajar siswa. Jadi pendidik hendaknya mengerti mengenai psikologi dan juga gejala-gejala psikologis yang timbul pada anak. Jika seorang pendidik tidak mengerti mengenai psikologi, maka akibatnya akan fatal. Anak didik tidak akan berkembang dengan baik, dan pendidik akan senantiasa membiarkan anak didik berkembang tanpa pengarahan yang jelas. ${ }^{3}$

Untuk mengatasi hal tersebut guru dituntut menggunakan metode yang dapat merangsang siswa untuk berpikir kritis dan realistis. Salah satu Metode pembelajaran yang tepat untuk diterapkan adalah Metode Mind Mapping yang merupakan suatu metode mempelajari konsep. Konsep-konsep ini didasarkan pada pada cara kerja

${ }^{1}$ Nur Rachma Permatasary And R. Indriyanto, "Interaksi Sosial Penari Bujangganong Pada Sale Creative Community Di Desa Sale Kabupaten Rembang," Mahasiswa Jurusan Sendratasik, Fakultas Bahasa Dan Seni, Universitas Negeri Semarang (2020)

${ }^{2}$ Eliana Yunitha Seran, Mardawani, Konsep Dasar IPS, (yogyakarta : CV BUDI UTAMA, 2021), Hlm 3

3 Muhammad Fathurrohman dan Sulistyorini. Belajar dan Pembelajaran, (Yogyakarta : Teras, 2012),hlm139. 
otak manusia untuk menyimpan sebuah informasi. ${ }^{4}$ Suyatno mengatakan bahwa mind map adalah metode pembelajaran yang dapat membantu peserta didik dalam mengingat informasi, mendapatkan ide, menghemat waktu, berkonsentrasi, dan dapat menuangkan imajinasi serta menumbuhkan kreativitas peserta didik. ${ }^{5}$

Hasil penelitian ini diharapkan dapat bermanfaat bagi guru yaitu sebagai bahan masukan bahwa terdapat banyak Metode pembelajaran yang dapat diterapkan untuk meningkatkan motivasi belajar siswa, salah satunya adalah Model Mind Mapping. Pada pembelajaran IPS tentang manusia sebagai makhluk sosial, artinya manusia itu perlu berinteraksi yang nantinya berdampak pada mobilitas sosial, perubahan sosial dan dinamika sosial. Selain itu dengan kita berinteraksi maka banyak kemungkinan akan menimbulkan suatu konflik dan integrasi yang terjadi.

\section{METODE PENELITIAN}

Penelitian ini menggunakan pendekatan kualitatif dengan jenis penelitian field research (penelitian lapangan). Jenis penelitian field research (penelitian lapangan) merupakan sebuah penelitian yang datanya diambil dan dilakukan di lapangan, seperti lingkungan masyarakat, lembaga maupun organisasi kemasyarakatan dengan menganalisis dan menyajikan data faktual secara sistematik tentang keadaan objek penelitian. Hal tersebut sejalan dengan definisi penelitian kualitatif yakni suatu penelitian yang memunculkan sebuah output data deskriptif berupa kata-kata tertulis atau lisan dari orang-orang dan perilaku yang dapat diamati. ${ }^{6}$

Pelaksanaan penelitian ini dilakukan di MI Mardhatillah Sanalaok Waru Pamekasan Madura. Adapun alasan pemilihan lokasi tersebut adalah karena salah satu peneliti merupakan salah seorang guru kelas dari sekolah MI Mardhatillah Sanalaok Waru Pamekasan Madura sehingga memudahkan peneliti dalam hal pengumpulan data. Data yang diperoleh dalam pelaksanaan penelitian ini bersumber dari subjek, informan penelitian serta literatur sebagai pendukung teori yang bersifat ilmiah.

\footnotetext{
${ }^{4}$ Gusti Wahyuni, dkk., Penerapan Mind Mapping Dengan Multimedia Dalam Peningkatan Pembelajaran IPA Pada Siswa Kelas V SD", Jurnal Hal 2.

${ }^{5}$ Suyatno, Menjelajah Pembelajaran Inovatif, (jawa timur: Masmedia Buana Pustaka,), hal 93.

${ }^{6}$ Lexy J. Moelong, Metode Penelitian Kualitatif, (Bandung: Remaja Rosdakarya, 2008) hal. 4
} 
Subjek yang dipilih dalam penelitian ini adalah guru kelas yang juga mengajar mata pelajaran Ilmu Pengetahuan Sosial di MI Mardhatillah Sanalaok Waru Pamekasan Madura. Sedangkan informan dalam penelitian yang dapat memberikan informasi terkait motivasi belajar siswa adalah kepala sekolah, wakil kepala sekolah bidang kurikulum, guru kelas dan peserta didik.

Adapun instrumen yang digunakan dalam penelitian yakni menggunakan observasi, wawancara dan angket sebagai pendukung. Observasi dilakukan untuk memperoleh informasi terkait pelaksanaan proses pembelajaran menggunakan Metode Mind Mapping. Kegiatan observasi ini dimaksudkan untuk memperhatikan langsung Metode Mind Mapping yang digunakan oleh guru dalam pelaksanaan proses belajar mengajar pada mata pelajaran Ilmu Pengetahuan Sosial di MI Mardhatillah Sanalaok Waru Pamekasan Madura, agar dapat menemukan data, informasi secara langsung dan alamiah dari kegiatan yang berlangsung. Sedangkan wawancara dilakukan untuk memperoleh data bagaimana potensi, kelebihan dan kelemahan yang dirasakan oleh guru dan peserta didik dalam proses belajar mengajar mata pelajaran Ilmu Pengetahuan Sosial selama menggunakan Metode Mind Mapping

Data pada penelitian ini berupa kata-kata, tulisan maupun tingkah laku yang dilakukan oleh para guru terkait dengan pemanfaatan Metode Mind Mapping pada mata pelajaran Pendidikan Agama Islam di MI Mardhatillah Sanalaok Waru Pamekasan Madura.

Jenis data dalam penelitian ini adalah berupa tekstual atau konsep-konsep. Karena dalam penelitian ini Sebagaimana telah disebutkan di atas termasuk kedalam jenis studi literatur. Dengan demikian aspek-aspek yang peneliti analisis melingkupi definisi, konsep, pandangan, pemikiran dan argumentasi yang terdapat dalam literatur yang relevan dengan pembahasan.

Dengan demikian, dalam penyusunan penelitian ini penulis menentukan topik yang akan dibahas yang kemudian dilanjutkan dengan mencari data-data baik itu yang relevan ataupun mendukung terhadap topik yang dibahas. Setelah mendapatkan data, penulis melakukan interpretasi atau penafsiran terhadap sumber data untuk memperoleh fakta tentang kajian yang akan dibahas. Setelah terkumpul maka data disusun secara sistematis dan terstruktur. 


\section{HASIL DAN PEMBAHASAN}

\section{Metode Pembelajaran Mind Mapping}

Penggunaan metode yang kurang bervariasi di MI Mardhatillah Sanalaok Waru Pamekasan khususnya di kelas IV menyebabkan kebosanan peserta didik dan kurangnya antusias mereka untuk belajar. Dalam hal ini guru memerlukan keterampilan dasar mengajar berupa adanya variasi mengajar siswa dan kemampuan merancang, mengimplementasikan berbagai strategi ataupun metode pembelajaran yang dianggap cocok dengan minat dan bakat serta sesuai dengan tarap perkembangan siswa.

Salah satu metode pembelajaran yang inovatif, dapat mengaktifkan peserta didik dan dapat meningkatkan daya ingat peserta didik terhadap materi pelajaran adalah metode Mind Mapping yang mana Metode Mind Mapping merupakan suatu metode mempelajari konsep. Konsep-konsep ini didasarkan pada pada cara kerja otak manusia untuk menyimpan sebuah informasi. ${ }^{7}$ Suyatno mengatakan bahwa mind map adalah metode pembelajaran yang dapat membantu peserta didik dalam mengingat informasi, mendapatkan ide, menghemat waktu, berkonsentrasi, dan dapat menuangkan imajinasi serta menumbuhkan kreativitas peserta didik. ${ }^{8}$

Mind mapping merupakan metode pembelajaran yang dapat membantu siswa dalam mengingat atau merekam materi yang didapatkan di sekolahan. Terlebih materi yang memiliki teori ataupun konsep yang cukup banyak dan metode ini bisa membuat peserta didik untuk lebih mempermudah dalam memahami konsep yang banyak tersebut. Dalam metode mind mapping ini mencoba untuk memfungsikan peran otak kanan dan juga otak kiri dalam pembelajaran agar saling belengkapi satu sama lain. ${ }^{9}$

Mind Mapping menjadi salah satu daya tarik peserta didik dalam proses pembelajaran, dikarenakan penggunaan mind mapping ini dapat membuat peserta didik lebih berkosentrasi dalam mengikuti kegiatan pembelajaran terlebih karena mind mapping ini merangsang kedua otak peserta didik untuk saling bekerja sama

\footnotetext{
${ }^{7}$ Ibid, Gusti Wahyuni

${ }^{8}$ Ibid, Suyatno

9 Siti Shalihah, "Otak, Bahasa, dan Pikiran Dalam Mind Map", Jurnal Al Faz, Vol 2 No 1, hal 194.
} 
memahami materi yang dipelajari. Rasa senang dan tertarik akan muncul dengan sendirinya seiring dengan penerapan mind mapping ini. Apalagi kalau guru menyajikannya dengan sikap yang menarik tentu akan menjadi nilai tambah dalam mencapai indicator pembelajaran yang direncanakan. ${ }^{10}$

\section{A. PEMBELAJARAN IPS}

\section{Perbedaan Pembelajaran IPS di MI, MTS dan MA}

Pada hakekatnya pengembangan pembelajaran Ilmu Pengetahuan Social (IPS) di Madrasah Ibtidaiyah (MI) berbeda dengan pembelajaran IPS di Madrasah Tsanawiyah. bahkan di Madrasah Aliyah. Yang mana substansi mata pelajaran IPS pada MI merupakan IPS terpadu. Pembelajaran pada kelas I s.d III dilaksanakan melalui pendekatan tematik sedangkan pada kelas IV s.d VI dilaksanakan melalui pendekatan mata pelajaran. Jam pembelajaran untuk setiap mata pelajaran dialokasikan sebagai mana tertera dalam struktur krikulum. Satua pendidikan dimungkinkan menambah maksimum empat jam pelajaran perminggu secara keseluruhan, dengan lokasi waktu satu jam pelajaran adalah 35 menit.

Secara umum struktur kurikulum MTS hampir sama dengan struktur kurikulum MI. Perbedaanya hanya terletak pada pemuatan mata pelajaran yaitu 10 mata pelajaran dan alokasi waktu satu jam pemelajaran, yaitu 40 menit $^{11}$

\section{Alasan Pendidikan IPS diajarkan di Madrasah}

Pembelajaran IPS akan memberikan informasi atau pengetahuan dan pemahaman tentang masyarakat serta wawasan kepada peserta didik mengenai siapa dirinya, masyarakatnya, bangsanya, dan perkembangan kehidupan kebangsaan di masa lalu, masa sekarang, dan yang akan datang. Tidak lupa pula adalah peran guru yang sangat penting agar transformasi ilmu ini menjadi baik dan tepat. Hal ini akan lebih baik apabila ditanamkan sejak dini karena akan mampu berpengaruh sebagai pedoman peserta didik dan diharapkan menjadi budaya bagi dirinya sendiri yang

${ }^{10}$ As Shoimin. Model Pembelajaran Inovatif Dalam Kurikulum 2013, (Yogyakarta: Ar Ruz Media, 2014

${ }^{11}$ Trianto Ibnu Badar At-Taubany, Dsain Pengembangan Kurikulum 2013 Di Madrasah, (Depok: Kencana, 2017), Hlm 90 
tentu akan berpengaruh kepada masyarakat sekitar. Sehingga pembelajaran IPS mampu memberi sumbangsih bagi masyarakat sekitar. ${ }^{12}$

\section{Sejarah perkembangan IPS}

Perkembangan pemikiran mengenai pendidikan IPS di Indonesia akan ditelusuri dari alur perubahan kurikulum IPS dalam dunia persekolahan dikaitkan dengan beberapa konten pertemuan ilmiah dan penelitian yang relevan dalam bidang itu,yang secara sporadis dan yang dapat dijangkau. Istilah IPS (Ilmu Pengetahuan Sosial), untuk pertama kalinya muncul dalam Seminar Nasional tentang Civic Education tahun 1972 di Tawangmangu Solo menurut laporaan Seminar tersebut (Panitia Seminar Nasional Civic Education,1972:2,dalam Winatapura,1978:42) ada 3 istilah yang muncul dan digunakan secara bertukar pakai (interchangeably), yakni: Pengetahuan Sosial, Studi Sosial,dan Ilmu Pengetahuan Sosial.

Ketiga istilah ini diartikan sebagai suatu studi masalah-masalah sosial yang dipilih dan dikembangkan dengan menggunakan pendekatan interdisipliner dan bertujuan agar masalah-masalah sosial itu dapat menghadapi dan memecahkan masalah sosial sehari-hari.Pada saat itu, konsep IPS tersebut belum masuk ke dalam kurikulum sekolah, tetapibaru dalam wacana akademis yang muncul dalam seminar tersebut. Kemunculan istilah tersebut bersamaan dengan munculnya istilah IPA (Ilmu Pengetahuan Alam) dalam wacana akademis Pendidikan Sains, pengertian IPS yang disepakati dalam seminar tersebut dapat dianggap sebagai pilar pertama dalam perkembangan pemikiran tentang pendidikan IPS. Berbeda dengan kemunculan pengertian social studies dari Edgar Bruce Wesley dalam pertemuan pertama NCSShun 1937 yang segera mendapat respons akademis secara meluas dan melahirkan kontroversi akademik, pemunculan pengertian IPS dengan mudah diterima dengan sedikit komentar. ${ }^{13}$

12 Rahmad, Kedudukan Ilmu Pengetabuan Sosial (IPS) Pada Sekolah Dasar, Jurnal Madrasah Ibtidaiyah, Vol. 2, No. 1, Oktober, 2016

${ }^{13}$ C. Marc, Teaching Social Studies,(New York: Prentice Hall, 1991), 9 


\section{B. INTRAKSI, MOBILITAS, PERUBAHAN,DAN DINAMIKA SOSIAL}

\section{Pengertian serta Contoh intraksi, mobilitas, perubahan,dan dinamika sosial}

Interaksi sosial adalah hubungan-hubungan sosial yang dinamis yang berkaitan dengan orang perorangan, kelompok perkelompok, maupun perorangan terhadap perkelompok ataupun sebaliknya. ${ }^{14}$ contohnya seperti kerjasama, mengajak teman bermain, menjadi seorang nara sumber dalam kegiatan seminar dll.

Mobilitas social adalah perpindahan seseorang atau sekelompok orang dari kedudukannya yang satu ke kedudukan yang lain. Dalam hal ini kedudukan dapat diartikan sebagai situasi tempat, status dan lain sebagainya. ${ }^{15}$ Contohnya seperti seseorang yang mengalami perubahan kedudukan status sosial baik dari yang lebih rendah ke yang lebih tinggi, maupun sebalknya.

Perubahan sosial adalah suatu variasi dari cara hidup yang telah diterima. Perubahan -perubahan itu terjadi baik karena perubahan-perubahan kondisi geografis, kebudayaan material,komposisi penduduk, idiologi maupun karena adanya difusi ataupun penemuan-penemuan baru dalam masyarakat ${ }^{16}$ contohnya seperti adanya inovasi pendidikan, gaya hidup, adanya inovasi tempat tinggal dll.

Dinamika sosial merupakan salah satu penelaahan sosiologi yang membahas tentang perubahan-perubahan yang terjadi didalam kehidupan sosial. ${ }^{17}$ Contohnya seperti segregasi sosial, pertumbuhan jumlah penduduk, dan pemecahan kelompok sosial.

\section{Proses terjadinya intraksi, mobilitas, perubahan,dan dinamika sosial}

Intraksi sosial terjadi karena adanya dua pihak yang saling kontak dan melakukan komunikasi. Intraksi sosial juga terjadi karena ada faktor pendorong seperti: faktor imitasi, faktor sugesti, faktor identifikasi, dan faktor simpati. ${ }^{18}$

\footnotetext{
${ }^{14}$ Elly M Setiadi \& Usman Kolip, Pengantar Sosiologi Pemahaman Fakta Dan Gejala Permasalahan Sosial: Teori, Aplikasi, Dan Pemecahannya (jakarta: kencana, 2011).

15 Elfahmi, F. K., Wahyudi, G. C., Yuliniati, S. H., \& Sari, S. I. P. 2018. Diferensiasi Dan Mobilitas Social. Malang.

16 Abdul Syani, Sosiologi Skematika, Teori, dan Terapan (Jakarta: PT. Bumi Aksara, 2007), 163

${ }^{17}$ Ibid. Elly M. Setiadi, Usman Kolip, hlm 49-51

18 Setiadi EM and R, Ilmu Sosial Budaya Dasar.
} 
Mobilitas terjadi ketika seseorang berpindah dari suatu posisi ke posisi lain, baik antarlapisan sosial berbeda maupun dalam lapisan sosial yang sama.Terjadinya mobilitas sosial berkaitan dengan hal-hal yang dianggap berharga dalam masyarakat. Oleh karena itu, kepemilikan atas hal-hal tersebut akan menjadikan seseorang menempati posisi atau kedudukan yang lebih tinggi. Akibatnya, dalam masyarakat terdapat penggolongan yang memengaruhi struktur sosial. Hal-hal tersebut antara lain kekuasaan, kehormatanm ilmu pengetahuan, dan kekayaan. ${ }^{19}$

Perubahan sosial terjadi karena adanya perubahan dalam unsur-unsur yang mempertahankan keseimbangan masyarakat, seperti perubahan dalam unsur-unsur geografis, biologis, ekonomis, dan kebudayaan. ${ }^{20}$

\section{Proses intraksi, mobilitas, perubahan,dan dinamika sosial bisa berlangsung}

Manusia adalah makhluk sosial yang memiliki akal pikiran juga kemampuan berinteraksi secara individu maupun sosial dan pada dasarnya manusia tidak mampu hidup sendiri di dalam dunia ini baik sendiri dalam kontek fisik maupun dalam kontek sosial budaya. Dalam kontek sosial budaya, manusia membutuhkan manusia lain untuk saling berkolaborasi dalam pemenuhan kebutuhan fungsi-fungsi sosial satu dengan lainnya dan semua masyarakat pada hakikatnya membudaya dan berkebudayaan Kecenderungan terjadinya perubahan-perubahan sosial merupakan gejala yang wajar yang timbul dari pergaulan hidup manusia di dalam masyarakat. Perubahan-perubahan sosial akan terus berlangsung sepanjang masih terjadi interaksi antarmanusia dan antarmasyarakat. ${ }^{21}$ Dari pernyataan tersebut dapat disimpulkan bahwa Proses intraksi, mobilitas, perubahan,dan dinamika sosial bisa berlangsung selama ada kehidupan di muka bumi ini.

\section{NILAI DAN NORMA SOCIAL}

\section{Pengertian Nilai Dan Norma Social}

Nilai sosial adalah nilai yang dianut oleh suatu masyarakat mengenai apa yang dianggap baik dan apa yang dianggap buruk oleh masyarakat. Menurut Horton dan

\footnotetext{
${ }^{19}$ http:/ / febbyrahayu02.blogspot.com/2016/11/proses-mobilitas-sosial.html, 26-oktober-2021

${ }^{20}$ https://e-journal.stp-ipi.ac.id/index.php/sapa/article/view/40, 26-oktober-2021

${ }^{21}$ Nur Rachma Permatasary and R. Indriyanto, "Interaksi Sosial Penari Bujangganong Pada Sale Creative Community Di Desa Sale Kabupaten Rembang," Mahasiswa Jurusan Sendratasik, Fakultas Bahasa dan Seni, Universitas Negeri Semarang (2020).
} 
Hunt dalam J. Dwi Narwoko dan Bagong Suyanto (2004:35) nilai adalah gagasan mengenai apakah suatu pengalaman berarti atau tidak berarti. Nilai pada hakikatnya mengarah pada perilaku dan pertimbangan seseorang. ${ }^{22}$ Sedangkan norma sosial: norma sosial merupakan hasil interaksi dari kelompok, maka nilai sosial sebenarnya sama dengan norma kelompok. Pengertian norma sosial dirumuskan oleh Sherif dalam (Gerungan: 2000: 103) sebagai pengertian umum yang seragam (antar anggota kelompok) mengenai cara-cara tingkah laku yang patut dilakukan oleh anggota kelompok apabila mereka dihadapkan dengan situasi yang bersangkut-paut dengan kehidupan kelompok. ${ }^{23}$

Perbedaan antara nilai dan norma sosial yaitu Nilai lebih dahulu muncul tercipta dibandingkan dengan norma., Norma muncul setelah adanya nilai dan berfungsi untuk mengikat pelaksanaan nilai. Nilai bersifat implisit alias tersamar / tersirat. Tidak ada nilai yang tertulis. Sebaliknya, norma bisa berwujud tertulis dan tidak tertulis. Nilai berfungsi sebagai pedoman, norma berguna sebagai aturan. Sedangkan Hubungan antara nilai dan norma sosial yaitu hubungan antara nilai \& norma yaitu, norma pada dasarnya merupakan sebuah nilai yang dibakukan atau dijadikan standar atau ukuran dalam menentuknan kualitas tingkah laku manusia. Nilai dan norma memegang peranan yang sangat penting dalam kehidupan sosial. Nilai merupakan sumber norma. Suatu masyarakat atau setiap orang menjalankan suatu norma demi mewujudkan nilai yang dicita-citakannya

\section{Macam-Macam Nilai Dan Norma Social}
a. Macam-Macam Nilai Sosial ${ }^{24}$ :

1)Nilai Material yaitu segala sesuatu yang berguna bagi unsur fisik atau jasmani manusia

2) Nilai Vital yaitu segala sesuatu yang berguna bagi manusia untuk mengadakan kegiatan dan aktivitas

3) Nilai Kerohanian yaitu segala sesuatu yang berguna bagi batin (rohani) manusia.

b. macam-macam norma sosial ${ }^{25}$

\footnotetext{
22 Bagong, Suyanto, J Dwi Narwoko, Sosiologi Teks Pengantar dan Terapan, Jakarta: Kencana Media Grup, (2004), hlm 35.

${ }^{23}$ Gerungan, Psikologi Sosial, Bandung: Rafika Pustaka Belajar, (tth), hlm 103.

${ }^{24}$ Herimanto, Ilmu Sosial \& Budaya Dasar, Jakarta: PT. Bumi Aksara, (2010), hlm 128.
} 
Norma agama, Norma kesusilaan, Norma kesopanan, Norma kebiasaan, Norma hukum

\section{Sumber Nilai Dan Norma}

a. Sumber nilai antara lain

1. Nilai yang Bersumber dari Tuhan (Nilai Theonom), Nilai sosial ini bersumber melalui ajaran agama yang tertulis di dalam kitab suci.

2. Nilai yang Bersumber dari Masyarakat (Nilai Heteronom), Masyarakat memiliki kesepakatan bersama mengenai suatu hal yang dianggap baik dan luhur, kemudian dijadikan sebagai pedoman dalam berperilaku sehari-hari. Contoh: sopan santun kepada kedua orang tua.

3. Nilai yang Bersumber dari Individu (Nilai Otonom), Pada dasarnya setiap orang memiliki sesuatu hal yang baik, penting, dan luhur.

b. sedangkan norma sosial antara lain

1. Norma Cara (Usage), yaitu suatu aturan yang apabila tidak diterapkan, maka pelaku hanya mengalami celaan.

2. Kebiasaan (Folkways), yaitu suatu aturan yang apabila tidak diterapkan, maka pelaku dianggap menyimpang dari kebiasaan umum di masyarakat

3. Tata Kelakuan (Mores), yaitu suatu aturan yang mengontrol perilaku dan memiliki sanksi di masyarakat.

4. Adat Istiadat (Custom), yaitu suatu aturan yang disepakati di kelompok masyarakat tertentu, berisi pedoman untuk bertingkah laku. Jika dilanggar, diberi hukuman berupa sanksi adat.

\section{Konsekwensi Serta Perilaku Menyimpang}

konsekwensi dari pelanggaraan nilai dan norma social yaitu Di cap oleh masyarakat sebagai pembandel, pembangkan, pelanggar bahkan penjahat. Mengalami gangguan kejiwaaan. Rasa bersalah. Dikucilkan. Diusir jika terjadi dalam kelompok masyarakat tertentu. Sanksi berupa hukuman. ${ }^{26}$

Perilaku menyimpang antara lain: Tindakan kriminal atau kejahatan, Penyimpangan Seksual. Pemakaian dan Pengedaran Obat Terlarang. Penyimpangan

${ }^{25}$ Wila Huky, Pengantar Sosiologi, Surabaya: Usaha Nasional, (1986), hlm 146.

26 Sosiologi, https://www.perpusku.com/2017/02/pelanggaran-nilai-dan-norma-sosial-besertasosial.html (diakes pada tgl 11 september 2021 pukul 09:12 WIB). 
Dalam Bentuk Gaya Hidup. sanksi bagi pelaku pembunuhan dijelaskan dalam bab jinayat ada 3 macam yaitu pertama sanksi asli berupa hukuman qisas sebagaimana disebutkan dalamAl-qur'an surah Al-baqarah ayat 178-197. Kedua sanksi pengganti berupa diat dan ta'zirsebagaimana disebutkan dalam Al-qur'an surah An-nisa' ayat 9293. Ketiga sanksi penyerta/tambahan berupa kafarat serta terhalang memperoleh waris dan wasiatsebagaimana disebutkan dalam Al-qur'an surah Al-maidah ayat $45 .^{27} \mathrm{Di}$ Indonesia sanksi bagi pelaku pembunuhan diatur dalam Kitab Undang-Undang Hukum Pidana(KUHP) Pasal 338-348 KUHP, mulai dari hukuman dipidana penjara paling sedikit 4 tahun dan selama-lamanya 15 sampai 20 tahun serta diancam pidana mati atau penjaraseumur hidup. ${ }^{28}$

\section{STRATIFIKASI SOSIAL DAN STRUKTUR SOSIAL}

\section{Pengertian Stratifikasi Sosial Dan Struktur Sosial}

Dalam ilmu sosiologi, struktur sosial digunakan untuk menjelaskan keteraturan sosial, yaitu menunjuk pada prinsip perilaku yang berulang-ulang dengan bentuk dan cara yang sama.Menurut Soerjono Soekanto (2002:68) struktur sosial diartikan sebagai hubungan timbal balik antarposisi sosial dan antarperan.Sedangkan Dalam sosiologi, lapisan-lapisan ini dinamakan lapisan sosial atau stratifikasi sosial. Stratifikasi sosial berasal dari bahasa Latin "stratum" (tunggal) atau "strate" (jamak) yang berarti berlapis-lapis. Menurut Pitirim A. Sorokin, stratifikasi sosial adalah pembedaan penduduk atau masyarakat ke dalam kelas-kelas secara bertingkat atau hierarkis. ${ }^{29}$

\section{Macam-Macam Stratifikasi Sosial Dan Struktur Sosial}

- Macam-macam Stratifikasi Sosial Menurut Soerjono Soekanto, macammacam stratifikasi sosial berdasarkan sifatnya dapat dibedakan menjadi beberapa bentuk, sebagai berikut:

${ }^{27}$ Shalih bin Fauzan al-Fauzan, Ringkasan Fikih Lengkap, Jilid I dan II, Penerjemah Asmuni, Jakarta: Darul Falah, 2005), hlm. 973.

${ }^{28}$ Ishaq, "Sanksi Pidana Pembunuhan dalam Hukum Pidana Indonesia dan Hukum Pidana Islam sebagai Kontribusi

Bagi Pembaruan Hukum Pidana Indonesia", Jurnal Al-risalah, Vol. 16, No. 1, (Juni 2016), hlm. 33-44.

${ }^{29}$ Vina Dwi Laning, Sosiologi Untuk SMA/MA Kelas XI, akarta: Pusat Perbukuan, Departemen Pendidikan Nasional, 2009, 20 
a. Stratifikasi sosial tertutup

Sistem lapisan sosial tertutup membatasi seseorang untuk pindah dari satu lapisan sosial ke yang lain. Satu-satunya jalan untuk menjadi menjadi bagian dari lapisan sosial tertentu adalah melalui kelahiran.Sistem lapisan sosial tertutup dapat ditemukan di India karena masih menganut sistem kasta. Seperti sistem kasta yang ada pada masyarakat bali. Adapun ciri-cirinya yaitu:

1) Anggotanya diperoleh melalui warisan atau kelahiran sehingga seseorang secara otomatis dan dengan sendirinya memiliki kedudukan seperti yang dimiliki orang tuanya.

2) Keanggotanya berlaku seumur hidup sehingga tidak mungkin seseorang bisa keluar dari keanggotaannya kecuali memang dikeluarkan atau dikucilkan.

3) Perkawinannya bersifat endogami, artinya pernikahan mereka hanya sekasta.

4) Hubungan dengan kelompok-kelompok sosial lain sangat terbatas.

5) Penyesuaian yang ketat terhadap norma-norma kasta.

b. Stratifikasi sosial terbuka

Pada sistem lapisan sosial ini, tiap orang berkesempatan naik ke lapisan sosial lebih tinggi karena kemampuannya sendiri.Sebaliknya, tiap anggota masyarakat juga bisa turun ke lapisan sosial yang lebih rendah. Contoh: seseorang yang awalnya sebagai buruh pekerja, kemudian membuka usaha dan sukses, sehingga menjadi pengusaha besar ataupun sebaliknya ketika seorang pengusaha mengalami kerugian sampai bangkrut.

c. Stratifikasi sosial campuran

Stratifikasi sosial campuran adalah gabungan antara stratifikasi sosial tertutup dan stratifikasi sosial terbuka. Agar bisa pindah ke lapisan sosial lain, maka seseorang harus pindah ke daerah yang lapisan sosialnya berkarakter terbuka. 
Contohnya, seseorang yang mempunyai kasta sudra dapat pindah ke daerah di mana masyarakatnya tidak mengenal sistem kasta. ${ }^{30}$

- $\quad$ Macam-Macam Struktur Sosial

Struktur sosial dalam fenomena kehidupan manusia dapat diklasifikasikan atas lima jenis sebagai berikut:

a. Struktur kaku dan luwes, atau struktur kaku bersifat tidak mungkin diubah atau sulit untuk diubah. Struktur luwes adalah struktur yang pola susunannya memungkinkan untuk diubah.

b. Struktur formal dan informal. Struktur formal atau resmi adalah struktur yang diakui pihak berwenang berdasarkan hukum yang berlaku.Adapun struktur informal atau tidak resmi adalah struktur yang nyata atau benar-benar ada serta berfungsi bagi masyarakat, tetapi tidak diakui oleh pihak berwenang dan tidak berketetapan hokum.

c. Struktur homogen dan heterogen. Struktur homogen adalah suatu struktur sosial yang unsur-unsurnya mempunyai pengaruh yang sama terhadap dunia luar. Struktur heterogen adalah suatu struktur yang unsur-unsurnya mempunyai kedudukan yang berbeda-beda dan kesempatan setiap unsur pun berbeda pula, baik terhadap kelompok sendiri maupun terhadap kelompok lain.

d. Struktur mekanis dan statistik. Struktur mekanis adalah suatu struktur yang menuntut persamaan posisi dari anggotanya agar dapat menjalankan fungsinya dengan baik.Struktur statistik adalah struktur yang dapat berfungsi dengan baik apabila persyaratan jumlah anggotanya terpenuhi.

e. Struktur atas dan bawah. Struktur atas atau suprastruktur umumnya diduduki oleh golongan orang yang memegang kekuasaan dalam bidang politik, ekonomi, dan sosial budaya.Struktur bawah atau infrastruktur adalah tempat bagi golongan masyarakat bawah atau mereka yang taraf kehidupannya relatif rendah. ${ }^{31}$

30Soekanto, Sosiologi Suatu Pengantar, (Jakarta: Raja Grafindo Persada, 2002), hal. 215

${ }^{31}$ Bagyu Waluya, Sosiologi (Menyelami Fenomena Sosial di Masyarakat), Jakarta: Pusat Perbukuan, 3-4. 
Sama seperti Talcott Parsons yang membangun teori Imperative Fungsional, Robert K. Merton meluncurkan kritik dari struktur fungsional Parsons untuk membangun teoi sosiologi (Merton, 1948: 164-68). Dengan fasih dan meyakinkan Merton mengemukakan bahwa para ahli sosiologi harus lebih maju lagi dalam peningkatan kedisiplinan dengan mengembangkan "teori-teori taraf menengah" dari pada teori-teori besar. Teori taraf menengah itu didefinisikan oleh Merton adalah sebagai teori yang terletak diantara hipotesa kerja yang kecil tetapi perlu, yang berkembang semakin besar selama penelitian dari hari ke hari, dan usaha yang mencakup semuanya mengembangkan suatu teori terpadu yang akan menjelaskan semua keseragaman yang diamati dalam perilaku sosial. ${ }^{32}$

\section{E. KONFLIK DAN INTEGRASI}

\section{Proses Terjadinya Konflik Dan Integrasi}

a. Proses Terjadinya Konflik ${ }^{33}$

Tahap I : Potensi Oposisi atau Ketidak cocokan, Langkah pertama dalam proses konflik adalah adanya kondisi (syarat) yang menciptakan kesempatan untuk kemunculan konflik itu. Kondisi itu tidak selalu langsung mengarah ke konflik, tetapi salah satu kondisi itu perlu agar konflik itu muncul.

Tahap II : Kognisi dan Personalisasi, Konflik yang Dipersepsikan merupakan kesadaran satu pihak atau lebih atas adanya kondisi yang menciptakan peluang terjadinya konflik. Konflik yang Dipersepsikan tidak berarti konflik itu dipersonalisasikan. Konflik yang Dirasakan, apabila individu-individu menjadi terlibat secara emosional dalam saat konflik, sehingga pihak-pihak mengalami kecemasan, ketegangan, frustasi, atau kekerasan. Tahap II ini penting karena persoalan konflik cenderung didefinisikan dan emosi memainkan peran utama dalam membentuk persepsi.

Tahap III : Maksud, Maksud merupakan keputusan untuk bertindak dalam cara teretntu.

${ }^{32}$ Ida Zahara Adibah, STRUKTURAL FUNGSIONAL ROBERT K. MERTON: Aplikasinya dalam Kehidupan Keluarga, INSPIRASI - Vol. 1, No. 1, Januari - Juni 2017, 174.

${ }^{33} \mathrm{http}$ ://perilakuorganisasikel5.blogspot.com/2014/06/konflik.html, 26-oktober-2021 
Tahap IV : Perilaku, Tahap perilaku mencakup: Pernyataan, Tindakan, Reaksi yang dibuat oleh pihak-pihak yang berkonflik

Tahap $V$ : Hasil, Hasil berupa jalinan aksi-reaksi antara pihak-pihak yang berkonflik menghasilkan konsekuensi.

b. Proses Terjadinya Integrasi ${ }^{34}$

Proses integrasi dapat dilihat melalui proses-proses berikut: yang pertama, Asimilasi (Assimilation), yakni suatu proses sosial yang ditandai dengan adanya usaha-usaha untuk mengurangi perbedaan-perbedaan yang ada di antara individu atau kelompok dalam masyarakat. Yang kedua, Akulturasi, yakni proses sosial yang terjadi bila kelompok sosial dengan kebudayaan tertentu dihadapkan pada kebudayaan asing yang berbeda. Proses akulturasi sudah ada sejak dahulu dalamsejarah kebudayaan manusia.

\section{Tahap konflik sehingga terjadi integrasi}

Konflik dilatar belakangi oleh perbedaan ciri-ciriyang dibawa individu dalam suatu interaksi. Perbedaan-perbedaan tersebut diantaranya adalah menyangkut fisik, kepandaian, pengetahuan, adat istiadat, keyakinan dan lain sebagainya. Konflik adalah sesuatu yang wajar terjadi di masyarakat, konflik hanya akan hilang bersamaan dengan hilangnya masayarakat itu sendiri. Konflik bertentangn dengan integrasi. Konflik dan integrasi berjalan sebagai sebuah siklus di masyarakat. Konflik yang terkontrol akan menghasilkan integrasi, sebaliknya, integrasi yang tidak sempurna dapat menciptakan konflik. $^{35}$

Konflik yang berkembang, seringkali menjadi ancaman serius atas keberlangsungan sistem sosial dalam masyarakat, akan tetapi fakta sosial seringkali menunjukkan, bahwa dalam proses konflik yang terjadi, pada tahap berikutnya diikuti pula dengan adanya proses integrasi yang mengarah pada penyatuan kembali satuansatuan sistem dalam masyarakat. ${ }^{36}$

\footnotetext{
${ }^{34}$ Kun Maryati, Juju Suryawati, Sosiologi Untuk SMA Dan MA Kelas XI, (Erlannga, 2006), Hlm70

35 Ali chaerudin dkk, Sumber Daya Manusia, (jawa barat: CV jejak, 2020), hlm302

36 Isa anshori(2008) Konflik dan Integrasi dalam kehidupan beragama. HALAQA: Jurnal Kependidikan dan KeIslaman, 7 (2). pp. 1-92. ISSN 1412-9302
} 


\section{Penyebab Konflik Dan Cara Mengatasinya}

\section{a. (Teori K.Robert Merton Dan Talcot Person)}

Implikasi teori Merton mengajak untuk lebih waspada jika kita akan melakukan suatu tindakan, karena mungkin keberhasilan dalam bertindak itu justru akan menciptakan masalah yang berat. ${ }^{37}$ Dari penjelasan tersebut dapat disimpulkan bahwa kita itu harus waspada dalam melakukan sesuatu agar hal tersebut tidak menimbulkan konflik. Waspada dalam hal ini maksudnya waspada seperti menjaga sikap, pembicaraan, dan waspada memunculkan terjadinya konflik dll. Talcott Parsons berpendapat bahwa semua tindakan harus terarah kepada tujuan (goal orientied) dan bahwa dalam mengejar tujuan-tujuan itu, kita memperhitungkan tujuan-tujuan orang lain. ${ }^{38}$ Artinya dalam melakukan sesuatu kita harus tau tujuan kita melakukan hal tersebut itu apa, karena kalau kita sudah tau pada tujuan kita kemudian di tujuan itu ada hal yang mengharuskan kita agar tidak melaksanakan perbuatan kita karena mungkin ada hal yang dapat menimbulkan konflik maka konflik itu tidak akan muncul.

\section{b. (Teori Kari Max, Dahrendorf Dan Max Weber)}

Teorikonflik dan teori structural fungsional. Secara umum dapat disimpulkan bahwa teori konflik menekankan pada perubahan-perubahan yang terjadi dalam kelompok masyarakat tertentu yang tanpa sadar dapat memicu terjadinya konflik. Selain itu, menurut teori konflik, setiap elemen masyarakat menyumbang atas persoalan yang terjadi dalam lingkungan social masyarakat. Sedangkan keteraturan atau integrasi adalah suatu paksaan dan tekanan yang dilakukan oleh pemimpin atau seseorang dengan otoritas kepada anggotanya. ${ }^{39}$

\section{KESIMPULAN}

Penggunaan metode yang kurang bervariasi di MI Mardhatillah Sanalaok Waru Pamekasan khususnya di kelas IV menyebabkan kebosanan peserta didik dan kurangnya antusias mereka untuk belajar. Dalam hal ini guru memerlukan

\footnotetext{
${ }^{37}$ Binti Maunah, Pendidikan Dalam Perspektif Struktural Fungsional, CENDEKIA, Vol. 10, No. 2, 2016

38 Rindra Sulistiono, Sinau Sosiologi, http://sinausosiologi.blogspot.com/2012/06/teori-strukturalfungsional-talcot.html?m=1

39 Anik Rahmaniah, Teori Konflik Ralf Dahrendorf, 2016, diakses dari http://repositry.uin-malang.ac.id/ pada 26-oktober-2021
} 
keterampilan dasar mengajar berupa adanya variasi mengajar siswa dan kemampuan merancang, mengimplementasikan berbagai strategi ataupun metode pembelajaran yang dianggap cocok dengan minat dan bakat serta sesuai dengan tarap perkembangan siswa. Untuk mengatasi hal tersebut guru dituntut menggunakan metode yang dapat merangsang siswa untuk berpikir kritis dan realistis. Salah satu metode pembelajaran yang inovatif, dapat mengaktifkan peserta didik dan dapat meningkatkan daya ingat peserta didik terhadap materi pelajaran adalah metode Mind Mapping yang mana Metode Mind Mapping merupakan suatu metode mempelajari konsep. Konsep-konsep ini didasarkan pada pada cara kerja otak manusia untuk menyimpan sebuah informasi.

\section{DAFTAR PUSTAKA}

Adibah Ida Zahara, STRUKTURAL FUNGSIONAL ROBERT K. MERTON: Aplikasinya dalam Kehidupan Keluarga, INSPIRASI - Vol. 1, No. 1, Januari Juni 2017, 174.

Anshori, Isa (2008) Konflik dan Integrasi dalam kebidupan beragama. HALAQA: Jurnal Kependidikan dan KeIslaman, 7 (2). pp. 1-92. ISSN 1412-9302

At-Taubany Trianto Ibnu Badar, Dsain Pengembangan Kurikulum 2013 Di Madrasah, Depok: Kencana, 2017

Al-Fauzan Shalih bin Fauzan, Ringkasan Fikih Lengkap, Jilid I dan II, Penerjemah Asmuni, Jakarta: Darul Falah, 2005

Bagong, Suyanto, J Dwi Narwoko, Sosiologi Teks Pengantar dan Terapan, Jakarta: Kencana Media Grup, 2004

Chaerudin Ali dkk, Sumber Daya Manusia, jawa barat: CV jejak, 2020

C. Marc, Teaching Social Studies,New York: Prentice Hall, 1991

Elfahmi, F. K., Wahyudi, G. C., Yuliniati, S. H., \& Sari, S. I. P. 2018. Diferensiasi Dan Mobilitas Social. Malang.

Fathurrohman Muhammad dan Sulistyorini. Belajar dan Pembelajaran, Yogyakarta : Teras, 2012

Gerungan, Psikologi Sosial, Bandung: Rafika Pustaka Belajar, (tth),

Herimanto, Ilmu Sosial \& Budaya Dasar, Jakarta: PT. Bumi Aksara, 2010

Huky Wila, Pengantar Sosiologi, Surabaya: Usaha Nasional, 1986

http://febbyrahayu02.blogspot.com/2016/11/proses-mobilitas-sosial.html, 26oktober-2021

https://e-journal.stp-ipi.ac.id/index.php/sapa/article/view/40, 26-oktober-2021 
http://perilakuorganisasikel5.blogspot.com/2014/06/konflik.html, 26-oktober-2021

Ishaq, "Sanksi Pidana Pembunuhan dalam Hukum Pidana Indonesia dan Hukum Pidana Islam sebagai Kontribusi Bagi Pembaruan Hukum Pidana Indonesia”, Jurnal Al-risalah, Vol. 16, No. 1, Juni 2016

Laning Vina Dwi, Sosiologi Untuk SMA/MA Kelas XI, akarta: Pusat Perbukuan, Departemen Pendidikan Nasional, 2009, 20

Maryati Kun, Juju Suryawati, Sosiologi Untuk SMA Dan MA Kelas XI, Erlannga, 2006

Maunah Binti, Pendidikan Dalam Perspektif Struktural Fungsional, CENDEKIA, Vol. 10, No. 2, 2016

Moelong Lexy J., Metode Penelitian Kualitatif, Bandung: Remaja Rosdakarya, 2008

Permatasary Nur Rachma And R. Indriyanto, "Interaksi Sosial Penari Bujangganong Pada Sale Creative Community Di Desa Sale Kabupaten Rembang," Mahasiswa Jurusan Sendratasik, Fakultas Bahasa Dan Seni, Universitas Negeri Semarang (2020)

Rindra Sulistiono, Sinau Sosiologi, http://sinausosiologi.blogspot.com/2012/06/teori-struktural-fungsionaltalcot.html?m=1

Rahmad, Kedudukan Ilmu Pengetahuan Sosial (IPS) Pada Sekolah Dasar, Jurnal Madrasah Ibtidaiyah, Vol. 2, No. 1, Oktober, 2016

Seran Eliana Yunitha, Mardawani, Konsep Dasar IPS, yogyakarta : CV BUDI UTAMA, 2021

Suyatno, Menjelajah Pembelajaran Inovatif, jawa timur: Masmedia Buana Pustaka

Shalihah Siti, "Otak, Bahasa, dan Pikiran Dalam Mind Map", Jurnal Al Faz, Vol 2 No 1, hal 194.

Shoimin As. Model Pembelajaran Inovatif Dalam Kurikulum 2013, Yogyakarta: Ar Ruz Media, 2014

Setiadi Elly M \& Usman Kolip, Pengantar Sosiologi Pemahaman Fakta Dan Gejala Permasalahan Sosial: Teori, Aplikasi, Dan Pemecahannya jakarta: kencana, 2011

Syani Abdul, Sosiologi Skematika, Teori, dan Terapan Jakarta: PT. Bumi Aksara, 2007

Setiadi EM and R, Ilmu Sosial Budaya Dasar.

Sosiologi, https://www.perpusku.com/2017/02/pelanggaran-nilai-dan-norma-sosialbeserta-sosial.html (diakes pada tgl 26 oktober 2021 pukul 09:12 WIB).

Soekanto, Sosiologi Suatu Pengantar, Jakarta: Raja Grafindo Persada, 2002

Waluya Bagyu, Sosiologi (Menyelami Fenomena Sosial di Masyarakat), Jakarta: Pusat Perbukuan, 3-4.

Wahyuni Gusti, dkk., Penerapan Mind Mapping Dengan Multimedia Dalam Peningkatan Pembelajaran IPA Pada Siswa Kelas V SD”, Jurnal Hal 2. 